\title{
Rancang Bangun Sistem Informasi Pengawasan Pelaksanaan Pekerjaan Studi Kasus PT. PLN Area Surabaya Utara
}

\author{
Mardiyanto \\ Program Studi Sistem Informasi \\ Institut Informatika Indonesia \\ mar.diyan87@gmail.com
}

\author{
Timothy John Pattiasina \\ Program Studi Sistem Informasi \\ Institut Informatika Indonesia \\ temmy@ikado.ac.id
}

\author{
Eddy Triswanto Setyoadi \\ Program Studi Sistem Informasi \\ Institut Informatika Indonesia \\ eddy@ikado.ac.id
}

\begin{abstract}
Abstrak - Sistem informasi berbasis komputerisasi merupakan salah satu faktor penting bagi perusahaan dalam mengelola segala aktifitasnya. Dalam hal ini, penerapan sistem informasi khususnya dalam pengawasan pekerjaan atau Surat Perintah Kerja (SPK) di perusahaan yang bergerak dalam pengelolaan proyek pekerjaan yang bekerjasama dengan pihak ketiga yang disebut juga dengan vendor atau mitra kerja masih sangat minim. Sistem Informasi Pengawasan Pelaksanaan Pekerjaan di PT PLN Area Surabaya Utara adalah suatu sistem yang dapat mengelola pendistribusian informasi pelaksanaan pekerjaan dan mampu menginformasikan status dari pelaksanaan pekerjaan tersebut. Sistem ini dibangun untuk mempermudah manajemen dalam mengelola pengawasan pelaksanaan pekerjaan atau Surat Perintah Kerja yang ada pada perusahaan. Selain itu sistem ini mampu memberikan notifikasi serta pengingat terhadap deadline pekerjaan melalui aplikasi berbasis XMPP yaitu Cangkruk yang sudah diterapkan di PT PLN Area Surabaya Utara.

Kata Kunci: Surat Perintah Kerja, Pengawasan, XMPP, PT PLN Area Surabaya Utara
\end{abstract}

\section{PENDAHULUAN}

Penerapan sistem informasi pengawasan pekerjaan di perusahaan yang bergerak dalam pengelolaan proyek pekerjaan yang bekerjasama dengan pihak ketiga atau mitra kerja masih sangat minim. Perihal tersebut terjadi juga di PT PLN Area Surabaya Utara yang bekerjasama dengan banyak mitra kerja untuk meningkatkan kinerja dan pelayanan perusahaan terhadap konsumennya.

PT PLN Area Surabaya Utara mempercayakan kepada banyak mitra kerja dalam hampir semua pekerjaan yang dilakukan baik investasi maupun operasional. Mitra kerja dalam melaksanaan proyek pekerjaan berdasarkan Surat Perintah Kerja (SPK) [1] yang telah disepakati dan telah melalui proses lelang pengadaan barang dan jasa. Selama masa pelaksanaan proyek pekerjaan, dilaksanakan proses pengawasan pekerjaan yang berada di unit kerja terkait baik di area maupun di rayon cabang pembantu.

Tenaga pengawas pekerjaan yang kompeten adalah hal yang mutlak untuk mendapatkan hasil pekerjaan yang baik dari mitra kerja. Hal tersebut untuk mengatasi beberapa kendala yang sering terjadi pada proses pengawasan pekerjaan ini, antara lain, pendistribusian informasi pelaksanaan pekerjaan yang tidak optimal, jumlah pengawas yang tidak sebanding dengan jumlah pekerjaan yang diawasi dan penentuan prioritas pekerjaan yang sulit dilakukan oleh pengawas pekerjaan.

Selain itu, manajemen menginginkan laporan pelaksanaan pekerjaan yang akurat dan jelas untuk menjadi pedoman dalam membuat perencanaan pekerjaan selanjutnya. Manajemen juga menginginkan integrasi sistem pengawasan ini dengan sistem yang sudah ada di lingkungan perusahaan diantaranya adalah aplikasi Cangkruk yang merupakan aplikasi messenger berbasis XMPP yang digunakan untuk komunikasi dan pertukaran informasi dan data antar pegawai.

Berdasarkan latar belakang permasalahan yang telah diuraikan maka perlu dirancang dan dibangun suatu sistem informasi pengawasan pelaksanaan pekerjaan yang dapat diterapkan di PT PLN Area Surabaya Utara. Diharapkan dengan adanya sistem ini dapat memberikan solusi terhadap permasalahan dari proses pelaksanaan pengawasan pekerjaan dan memberikan output informasi yang baik dan benar.

\section{METODOLOGI PENELITIAN}

Telah diketahui pada pendahuluan bahwa terdapat beberapa hal yang berperan penting dalam perancangan dan pembuatan sistem informasi pengawasan pelaksanaan pekerjaan ini. Hal-hal tersebut akan dijabarkan pada sub-bab dibawah ini:

\section{A. Sistem Informasi}

Data dan informasi sangat berkaitan dengan pengertian dari sistem informasi sebagai entitas penting pembentuk sistem informasi. Data merupakan nilai, keadaan atau sifat 
yang berdiri sendiri dan terlepas dari konteks apapun. Sementara sistem informasi adalah data yang telah diolah menjadi sebuah bentuk yang berarti bagi penerimanya dan bermanfaat dalam pengambilan keputusan saat ini atau mendatang. Sedangkan definisi lain informasi adalah data yang telah diproses atau data yang memiliki arti.

Sistem informasi mempunyai 3 (tiga) konsep yaitu:

- Input

- Proses

- Output

Konsep berawal dari input data yang mengalami pemrosesan dan pada akhirnya mengeluarkan hasil berupa output data.

\section{B. Basis Data}

Basis data adalah sekumpulan data yang saling berelasi. Basis data sendiri merupakan representasi digital dari kenyataan fisik dan logic dari sebuah sistem. Mentransformasikan kenyataan dari sebuah sistem ke basis data bukanlah sebuah pekerjaan sederhana. Kita membutuhkan media antara. Orang menyebutnya sebagai model data, sebagai wujud dari perancangan basis data. Setiap orang yang terlibat didalam pembangunan dan penerapan teknologi informasi harus menyadari bukan hanya pentingnya basis data dan model data, akan tetapi juga pada betapa pentingnya hal membuat model data yang baik.

\section{Database Management System}

Sistem manajemen basis data atau database management system (DBMS) adalah suatu perangkat lunak yang ditujukan untuk menangani penciptaan, pemeliharaan dan pengendalian akses data [2]. Dengan menggunakan perangkat lunak ini pengelolaan data menjadi mudah dilakukan. Keuntungan dari database management system antara lain pengulangan data berkurang, intregitas data meningkat, keamanan data meningkat dan kemudahan pemeliharaan data.

\section{Data Flow Diagram}

Data flow diagram digunakan untuk mendokumentasikan aliran dokumen dari satu set prosedur atau proses. Dalam hal ini diagram aliran data digunakan untuk menunjukkan aliran dokumen (informasi) dalam merancang sistem informasi.

Simbol-simbol yang digunakan dalam sebuah data flow diagram, yaitu:

\section{- Simbol proses}

Simbol ini melambangkan suatu proses yang bertugas mengolah data yang masuk dan memberikan data ke proses atau entitas lain. Setiap proses memiliki identitas proses dan nama proses.

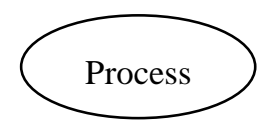

Gambar 1. Simbol Proses

\section{- Simbol external entity}

External entity adalah kesatuan di lingkungan luar sistem yang dapat berupa orang, organisasi, atau sistem lainnya yang berada di lingkungan luar yang memberikan masukan (input) atau menerima keluaran (output) dari sistem.

$$
\text { external entity }
$$

Gambar 2. Simbol external entity.

\section{- Simbol data stores}

Simbol data stores merupakan tempat penyimpanan data yang terdapat dalam sistem tersebut. Tempat penyimpanan data yang dimaksud dapat berupa file atau database di sistem komputer.

\section{Data Store}

Gambar 3. Simbol Data Store.

\section{- Simbol aliran data}

Arus data menunjukkan aliran data antara proses dengan entitas dan proses dengan tempat penyimpanan (data stores).

\section{$\longrightarrow$ Data Flow $\longrightarrow$ \\ Gambar 4. Simbol Data Flow.}

Diagram aliran data dapat dibagi atas beberapa level yang tergantung dari apakah proses di diagram tersebut masih mewakili beberapa proses lainnya, jika benar maka diagram aliran data untuk level berikutnya masih diperlukan. DFD level 0 disebut juga context diagram, dimana semua entitas yang terkait dalam suatu sistem informasi dapat digambarkan beserta hubungannya (secara umum). Dari DFD level 0 dapat dikembangkan ke DFD level 1 dan seterusnya sesuai dengan proses yang diwakilinya

\section{E. PHP}

PHP singkatan dari PHP Hypertext Preprocessor. PHP merupakan bahasa berbentuk skrip yang ditempatkan dalam server dan diproses di server [3]. Hasilnya yang dikirimkan ke klien, tempat pemakai menggunakan browser. Dengan menggunakan PHP, website akan lebih interaktif dan dinamis. Artinya dapat membentuk tampilan berdasarkan permintaan terkini. Pada prinsipnya PHP mempuyai fungsi yang sama dengan skrip - skrip seperti ASP, Cold Fusion maupun JSP. Kemudahan lain dari PHP adalah mampu berintegrasi dengan berbagai macam database salah satunya MySQL[4].

\section{F. MySQL}

MySQL adalah sebuah implementasi dari sistem manajemen basis data relasional yang didistribusikan secara gratis dibawah lisensi GPL (General Public License). Setiap pengguna dapat secara bebas menggunakan MySQL, namun dengan batasan perangkat lunak tersebut tidak boleh dijadikan produk turunan yang bersifat komersial. MySQL 
sebenarnya merupakan turunan salah satu konsep utama dalam basis data yang telah ada sebelumnya yaitu SQL (Structured Query Language). SQL adalah sebuah konsep pengoperasian basis data, terutama untuk pemilihan atau seleksi dan pemasukan data, yang memungkinkan pengoperasian data dikerjakan dengan mudah secara otomatis.

\section{G. Teori Pengawasan}

Terselenggaranya pengawasan dalam sebuah institusi yakni untuk menilai kinerja suatu institusi dan memperbaiki kinerja sebuah institusi. Oleh karena itu dalam setiap perusahaan mutlak, bahkan rutin adanya sistem pengawasan [5]. Dengan demikian pengawasan merupakan instrumen pengendalian yang melekat pada setiap tahapan operasional perusahaan. Fungsi pengawasan dapat dilakukan setiap saat, baik selama proses manajemen atau administrasi berlangsung maupun setelah berakhir untuk mengetahuai tingkat pencapaian tujuan suatu organisasi atau kerja. Fungsi pengawasan dilaksanakan, agar diperoleh umpan balik (feed back) untuk melaksanakan perbaikan bila terdapat kekeliruan atau penyimpangan sebelum menjadi lebih buruk dan sulit diperbaiki.

\section{HASIL DAN PEMBAHASAN}

Agar pengembangan aplikasi lebih maksimal, melakukan analisa terhadap aplikasi sangat penting, sehingga sistem yang akan dibangun memiliki acuan dan gambaran umum.

\section{A. Context Diagram}

Context diagram merupakan gambaran secara umum hubungan aliran data diantara entitas yang terkait dalam suatu sistem informasi sehingga dapat dilihat secara garis besar aliran data yang terjadi. Untuk gambaran lebih jelas tentang context diagram perancangan dan pembuatan sistem informasi pengawasan pelaksanaan pekerjaan di PT PLN Area Surabaya Utara dapat dilihat pada gambar context diagram berikut

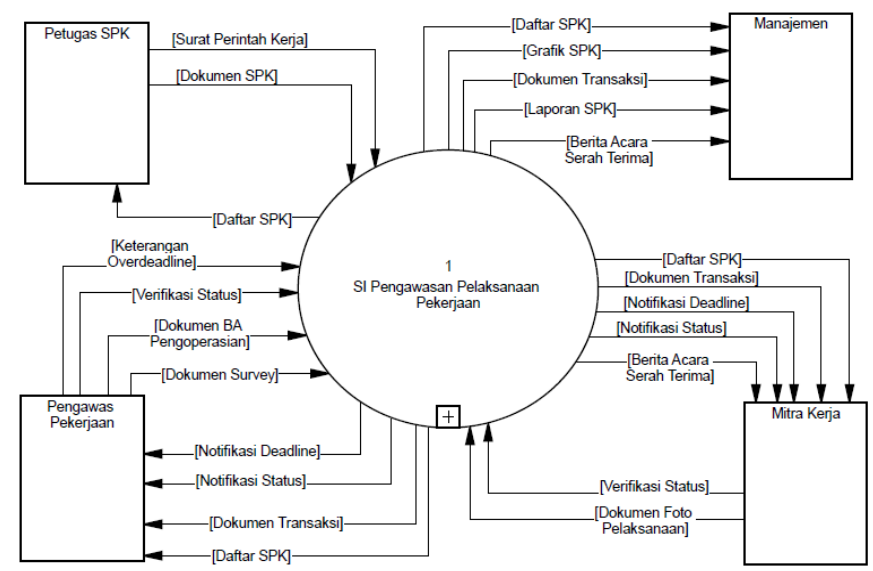

Gambar 5. Context Diagram.
Pada gambar tersebut terdapat 4 entitas yang terlibat dalam sistem, yaitu Petugas SPK, Pengawas Pekerjaan, Mitra Kerja dan Manajemen. Petugas SPK memasukan data Surat Perintah Kerja (SPK) dan mengunggah Dokumen SPK ke dalam sistem, selain itu Petugas SPK mendapat data Daftar SPK dari sistem. Pengawas Pekerjaan mendapatkan data Daftar SPK, Dokumen Transaksi, Notifikasi Status apabila ada perubahan status transaksi dan Notifikasi Deadline apabila transaksi mendekati atau melebihi tenggat waktu pekerjaan dari sistem, selain itu Pengawas Pekerjaan memasukan Dokumen Survey, Dokumen Berita Acara (BA) Pengoperasian, Verifikasi perubahan Status transaksi dan memasukan Keterangan Overdeadline apabila transaksi melewati tenggat waktu pekerjaan. Mitra Kerja mendapatkan data Daftar SPK, Dokumen Transaksi, Notifikasi Status, Notifikasi Deadline dan Berita Acara Serah Terima (BAST), selain itu Mitra Kerja memasukan Dokumentasi Foto Pelaksanaan untuk update pelaksanaan pekerjaan, Verifikasi perubahan Status transaksi dan Berkas Akhir Update Data Induk Jaringan (DIJ). Manajemen mendapatkan data Daftar SPK, Dokumen Transaksi, Laporan SPK, Grafik SPK dan Berita Acara Serah Terima. Context Diagram tersebut kemudian didekomposisi menjadi beberapa proses lagi menjadi Data Flow Diagram (DFD) level 1 untuk mempermudah analisa proses bisnis.

\section{B. Data Flow Diagram (DFD) Level 1}

DFD level 1 ini merupakan dekomposisi dari context diagram dan berisikan 4 proses utama, yaitu Input Data SPK, Transaksi Pekerjaan, Penampilan Dashboard dan Pembuatan Laporan. Gambar dari DFD level 1 dapat dilihat pada gambar berikut.

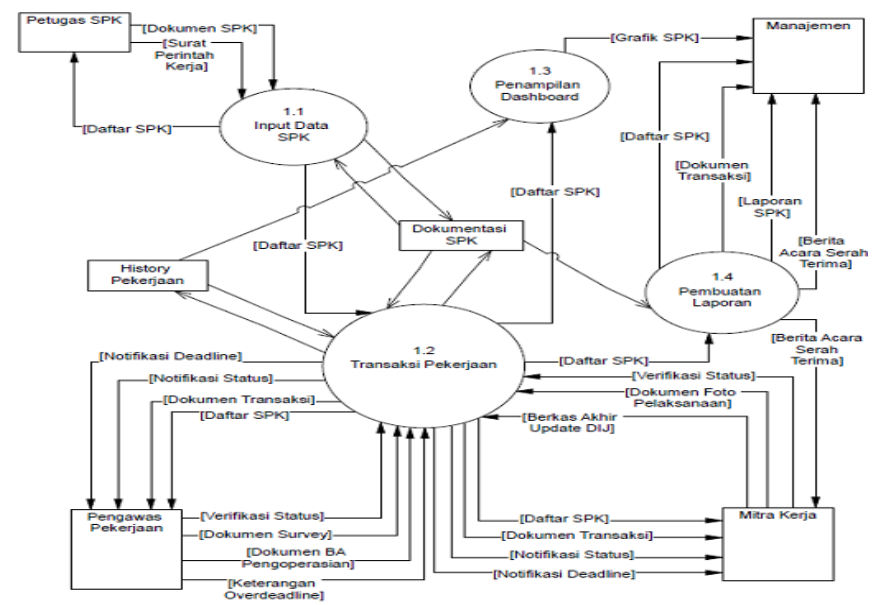

Gambar 6. DFD Level 1. 
Proses input data SPK adalah proses memasukan data keterangan pekerjaan dari data dokumen SPK yang ada serta mengunggah hasil scan dokumen SPK ke dalam sistem. Proses transaksi pekerjaan berisikan aliran data tentang status pekerjaan dan perubahan terhadap status pekerjaan tersebut serta scan dokumen pelaksanaan pekerjaan. Proses penampilan dashboard memberikan informasi berupa grafik tentang kondisi dari status pelaksanaan pekerjaan. Proses pembuatan laporan berisikan proses dalam menghasilkan laporan pelaksanaan pekerjaan bagi manajemen.

\section{Desain Arsitektur Sistem}

Desain aristektur dari sistem yang akan dibangun dapat dijelaskan sebagai berikut. Server database dan web diletakkan di dalam lokasi kantor PT PLN Area Surabaya Utara. Semua user dapat mengakses sistem karena sistem dihubungkan dengan jaringan intranet dan internet dari PT PLN Area Surabaya Utara. User Petugas SPK, Pengawas Pekerjaan dan Manajemen dapat mengakses melalui komputer ataupun perangkat mobile lainnya ketika beraktivitas di dalam kantor PT PLN. Sedangkan untuk user yang berada di luar kantor PLN seperti Mitra Kerja dan user lain yang tidak sedang berada di dalam lokasi kantor PT PLN, dapat mengaksesnya melalui jaringan internet melalui perangkat mobile lainnya juga. Untuk lebih jelas akan diterangkan dengan gambar 7 .

\section{Desain Basis Data}

Untuk perancangan basis data relasional sistem ini, digunakan entity relationship diagram (ERD). Dari hasil analisa dengan ERD, didapatkan 11 entitas dalam sistem ini yang akan dibuat. Relasi antar entitas yang dihasilkan berjumlah 7 buah dengan 4 relasi yang menyatakan hubungan one to many dan 3 relasi yang menyatakan hubungan many to many. Terdapat 3 entitas yang memiliki relasi ber-parent. Dan terdapat pula 2 entitas yang tidak berelasi dengan entitas yang lain.

Pengembangan dari ERD tersebut dikembangkan menjadi Conceptual Data Model (CDM) yang selanjutnya menjadi Physical Data Model (PDM) yang memperlihatkan bahwa relasi many to many akan menjadi tabel tersendiri dengan memiliki primary key sendiri dan foreign key yang diambil dari primary key tabel-tabel yang memiliki relasi many to many tersebut. PDM tersebut kemudian diolah untuk dijadikan script SQL untuk membuat basis data relasional sesuai dengan sistem yang dianalisa.

Berikut adalah gambar dari model entity relationship diagram sistem pada gambar 8 dan gambar physical data model sistem pada gambar 9.

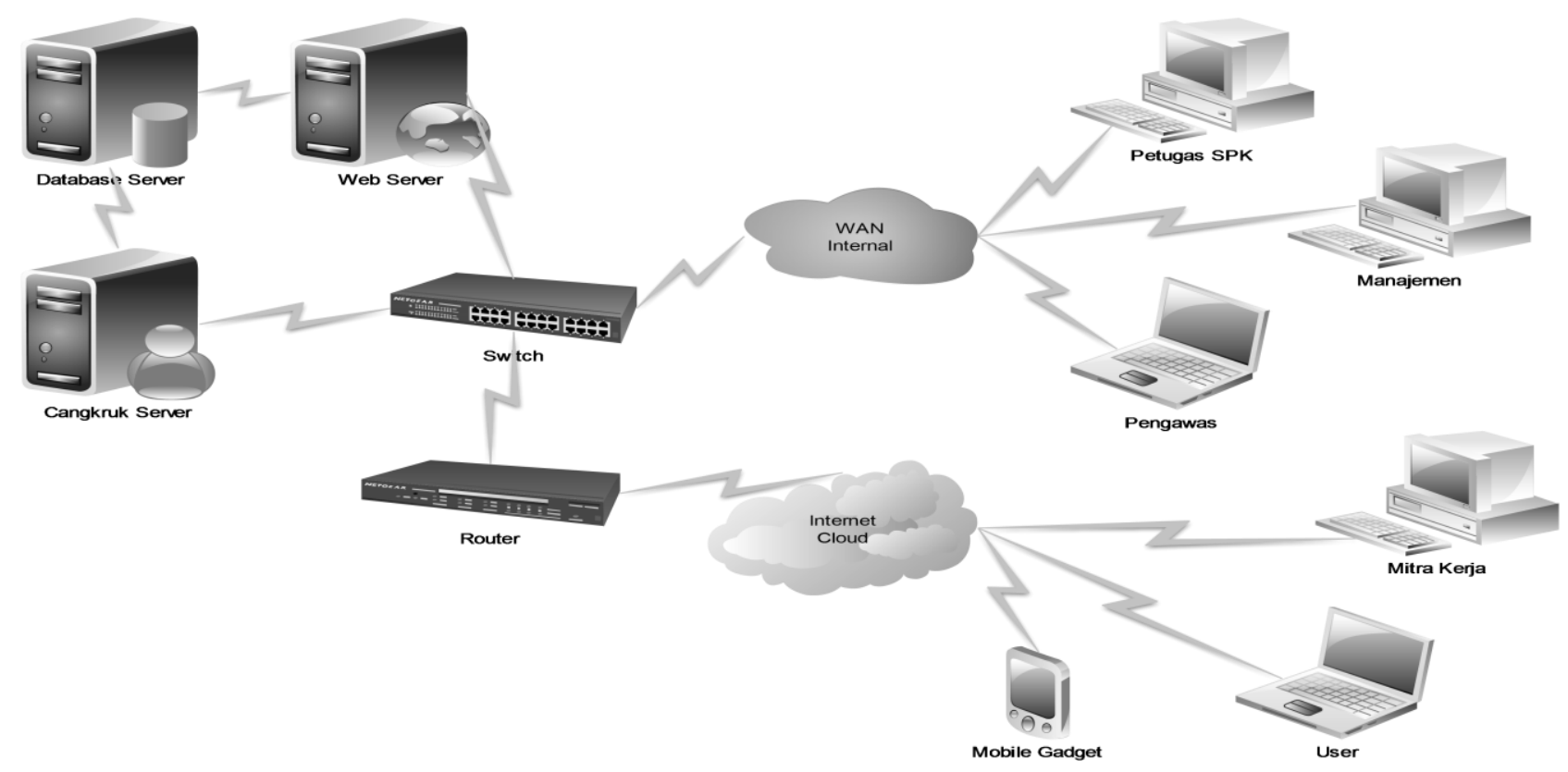

Gambar 7. Desain Arsitektural. 


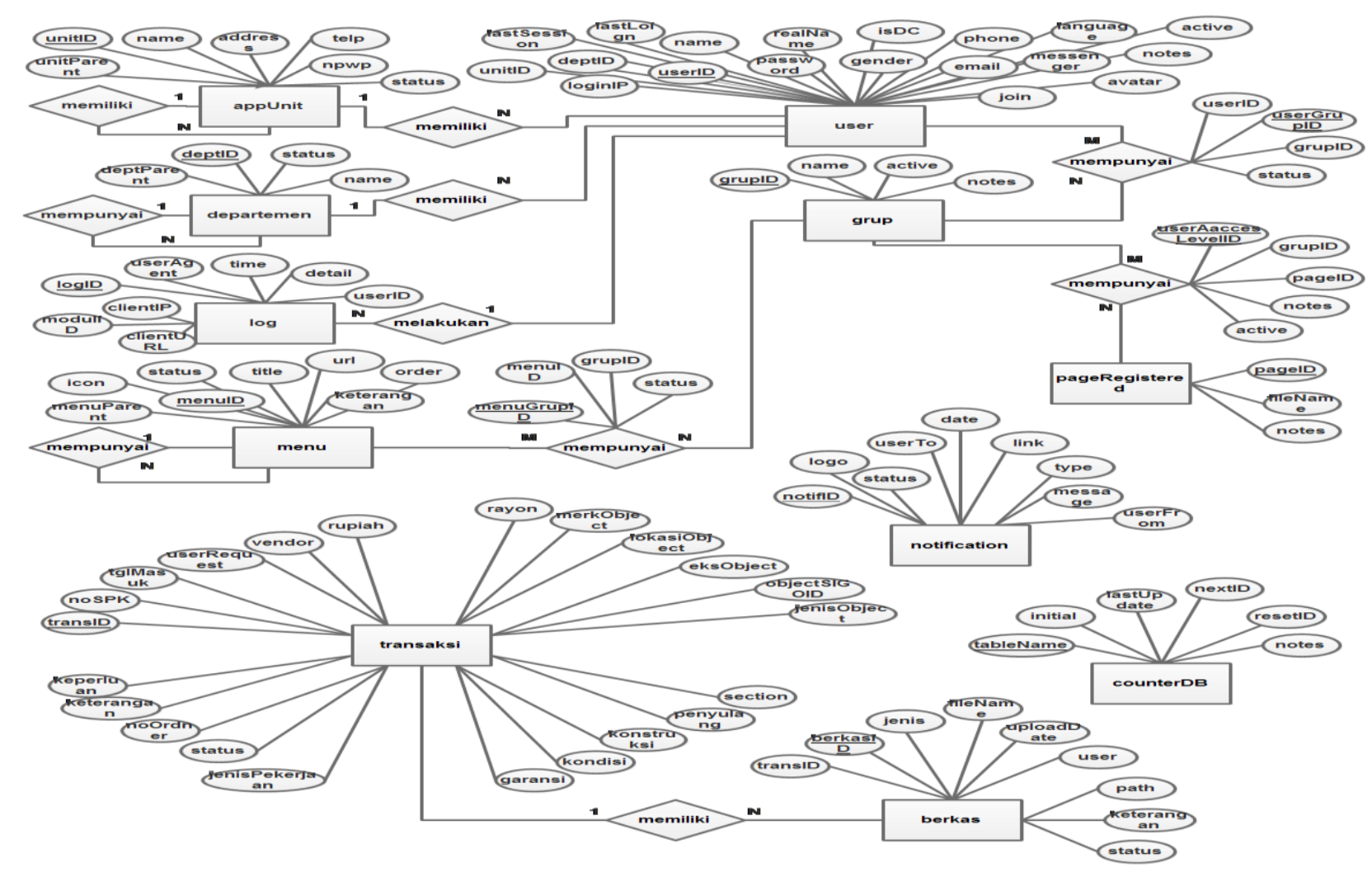

Gambar 8. Entity Relationship Diagram.

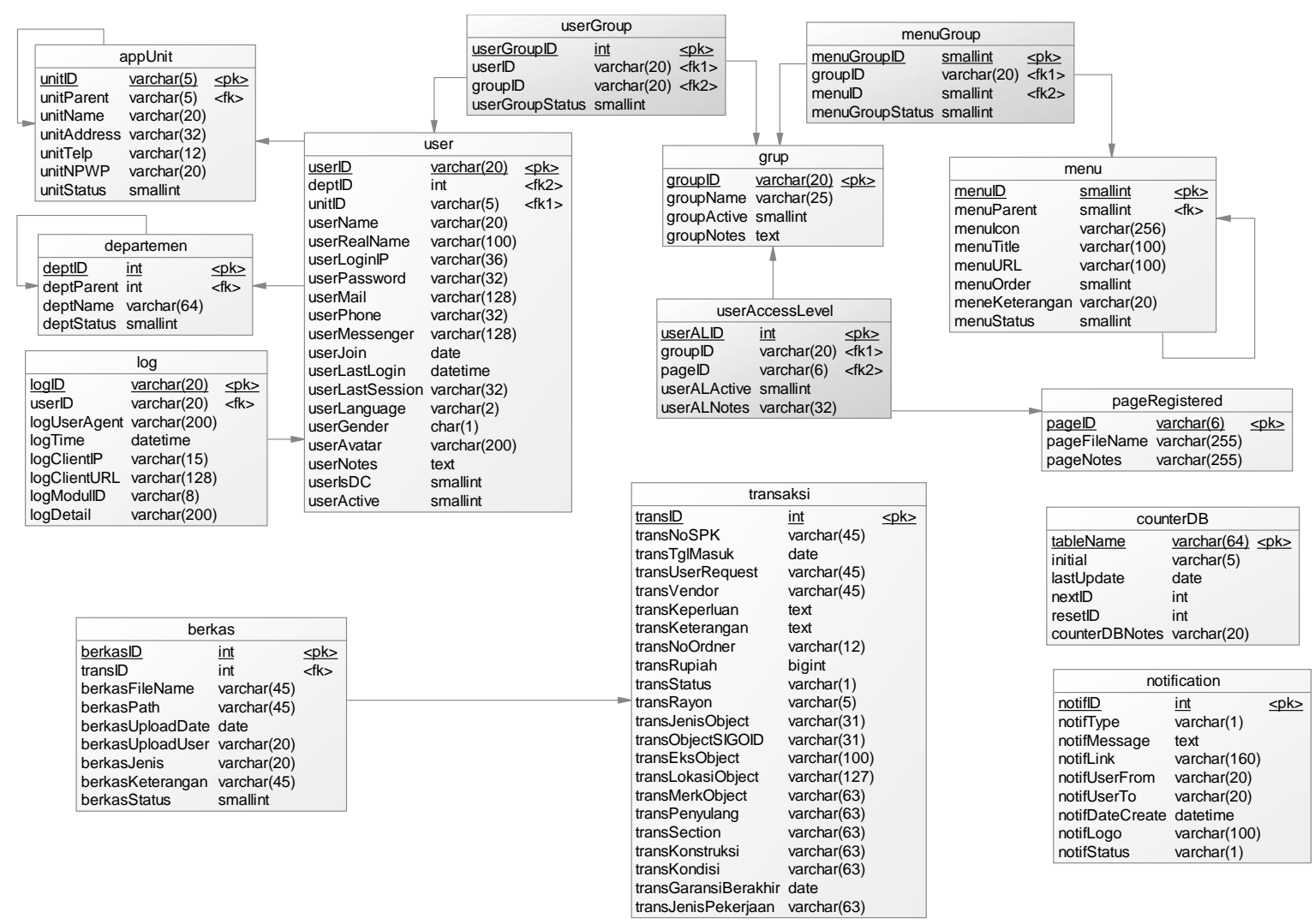

Gambar 9. Physical Data Model. 


\section{E. User Interface}

Pada sub bab ini akan ditunjukkan tampilan antar muka dari aplikasi sistem informasi pengawasan pelaksanaan pekerjaan yang akan dibangun.

\section{- Form Login}

Form Login digunakan sebagai pintu masuk ke dalam sistem. Selain sebagai pintu masuk ke dalam sistem, digunakan juga untuk membatasi pihak-pihak yang tidak berkepentingan untuk masuk ke dalam sistem.

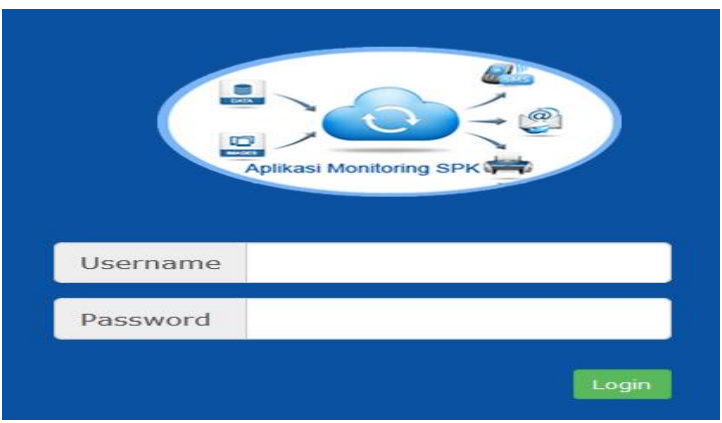

Gambar 10. Form Login.

\section{- Form Menu Utama}

Setelah user login ke dalam sistem, maka user akan menjumpai halaman Menu Utama yang berisikan gambar home menu dan beberapa menu di bagian header form Menu Utama. Menu-menu yang terdapat pada header jumlahnya berbeda-beda tergantung kebutuhan user yang login pada sistem.

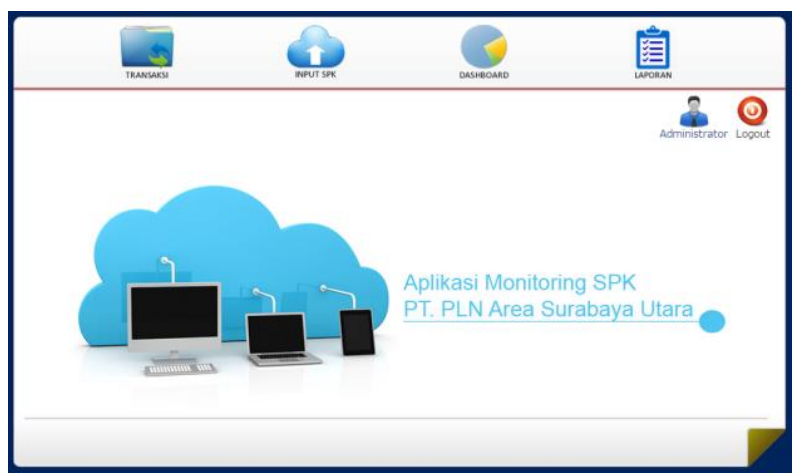

Gambar 11. Form Menu Utama.

\section{- Form Input Data SPK}

Form Input Data SPK merupakan awal dari dimulainya proses dari Sistem Pengawasan Pelaksanaan Pekerjaan ini. Menu ini hanya dapat diakses oleh user Petugas SPK. Pada menu ini, user mengisi data transaksi pekerjaan dengan menggunakan komponen-komponen yang ada seperti tampak pada gambar.

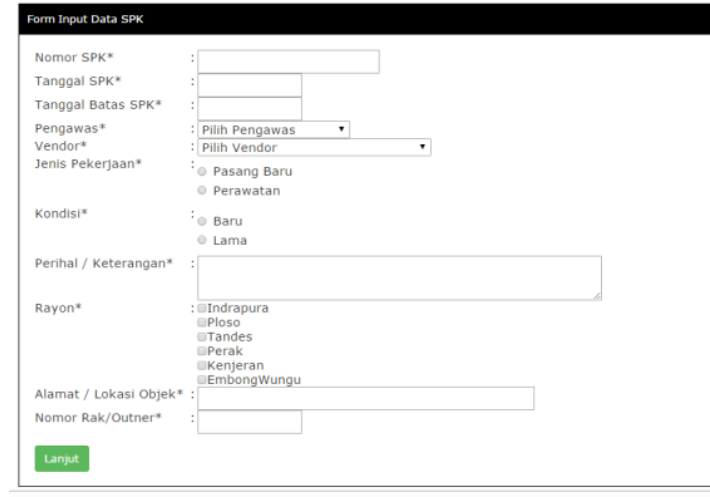

Gambar 12. Input Data SPK.

Apabila transaksi berhasil dimasukan maka akan muncul notifikasi pada aplikasi Cangkruk ke user pengawas pekerjaan dan mitra kerja yang terkait seperti pada gambar berikut.

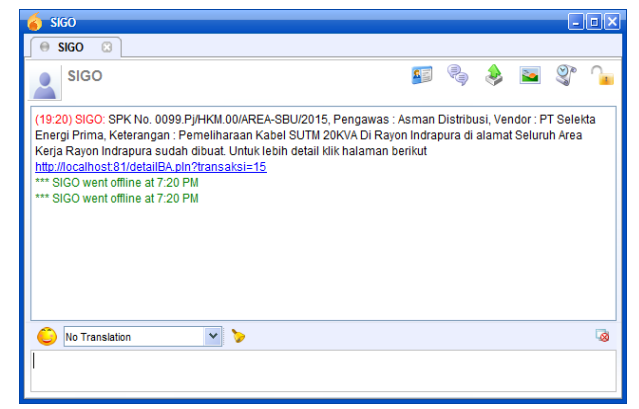

Gambar 13. Notifikasi di Aplikasi Cangkruk.

\section{- Form Upload File Transaksi}

Form ini tampil setelah transaksi berhasil dimasukan ke dalam sistem. Pada form ini, user diberikan informasi tentang transaksi yang sudah dimasukan ke dalam sistem. User dapat meng-upload dokumendokumen yang diperlukan seperti hasil scan dokumen SPK ke dalam sistem.

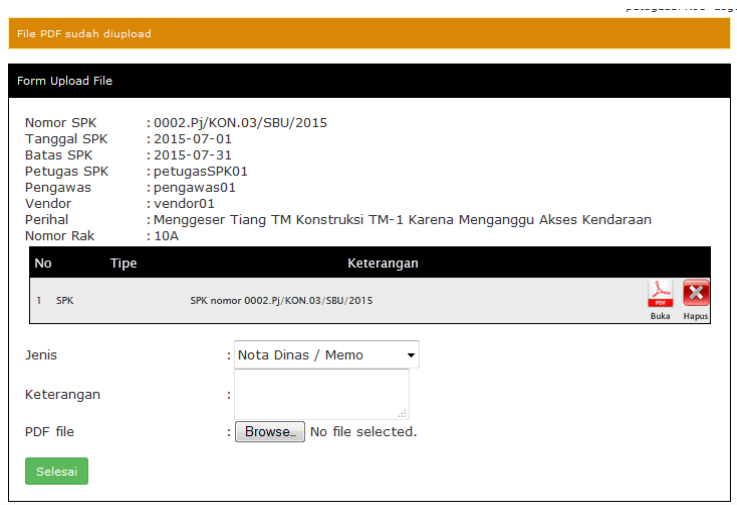

Gambar 14. Form Upload File Transaksi.

\section{- Form Menu Transaksi}

Pada menu Transaksi, user dapat melihat daftar pekerjaan yang ditangani oleh user terebut masing- 
masing. Terdapat text box dengan bantuan Nomor SPK atau Perihal/Keterangan untuk memudahkan pencarian pekerjaan yang ingin diproses. Tiap user memiliki tampilan yang berbeda pada button Status yang ada pada daftar pekerjaan.

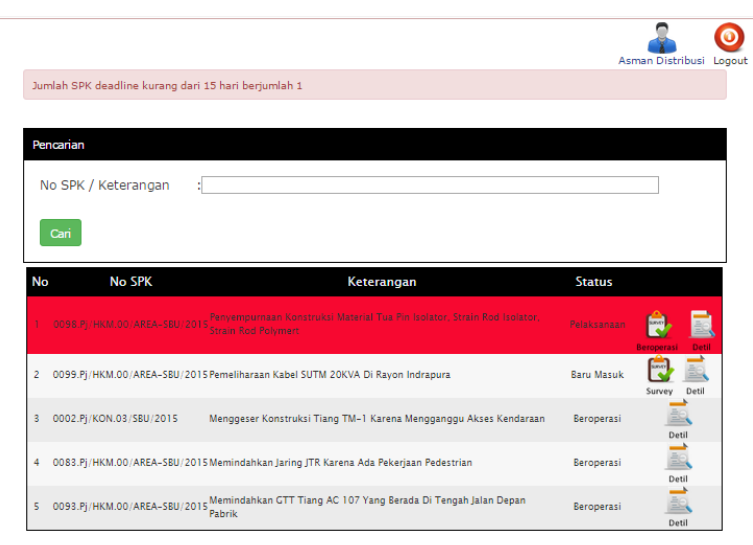

$\mid \varangle\langle|1||\gg|$

Gambar 15. Tampilan Daftar Pekerjaan.

Selain menggunakan pesan pengingat pada bagian atas menu Transaksi, user yang memiliki transaksi yang mendekati deadline juga akan mendapatkan notifikasi melalui aplikasi Cangkruk setiap harinya secara otomatis seperti yang terlihat pada gambar.

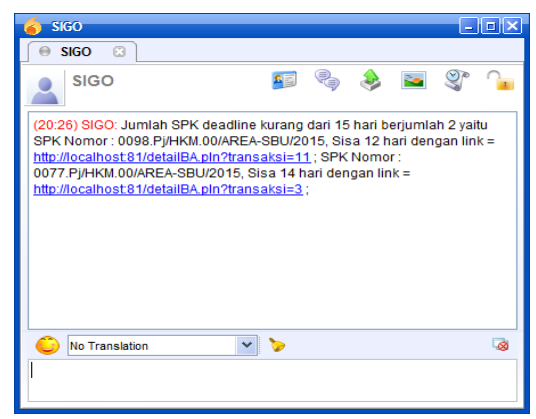

Gambar 16. Notifikasi Deadline Transaksi.

Dengan menekan button status pada menu Transaksi, maka sistem secara otomatis juga mengirim notifikasi kepada user yang terkait dengan proses pelaksanaan pekerjaan tersebut melalui aplikasi Cangkruk.

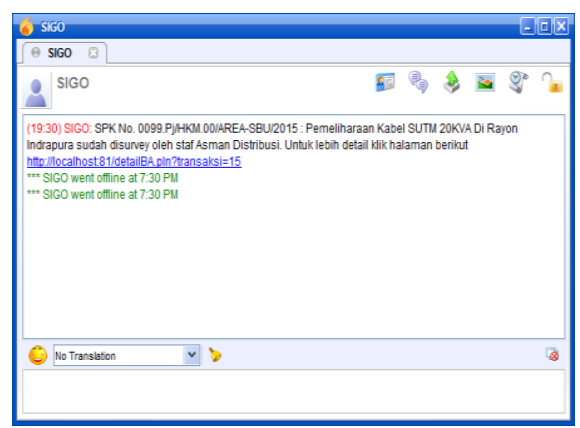

Gambar 17. Notifikasi Status Transaksi.
Notifikasi tersebut juga memberikan link menuju halaman form detil transaksi seperti yang diperlihatkan pada gambar.

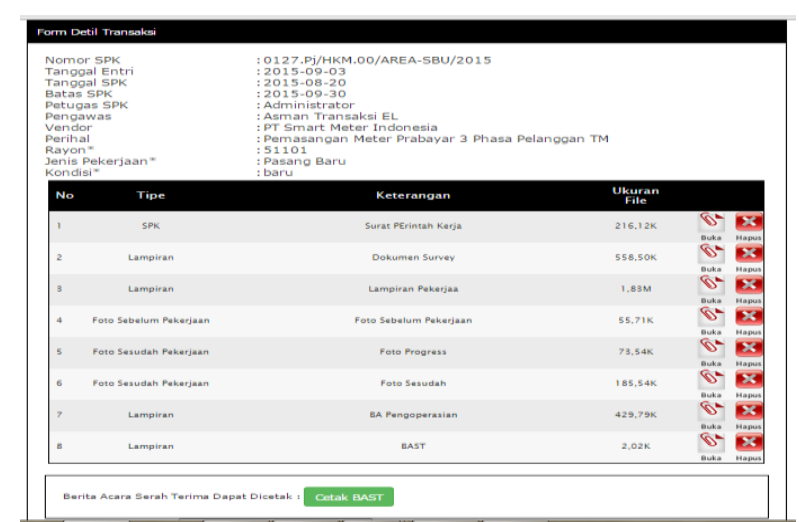

Gambar 18. Form Detail Transaksi.

Sub-form button Cetak BAST pada form detil transaksi akan aktif apabila status transaksi sudah beroperasi, Sub-form ini hanya dapat diakses melalui form detil transaksi pada user Manajemen dan Mitra Kerja. Dan apabila di-submit akan keluar laporan Berita Acara Serah Terima seperti pada gambar

BERITA ACARA

SERAH TERIMA PEKERJAAN

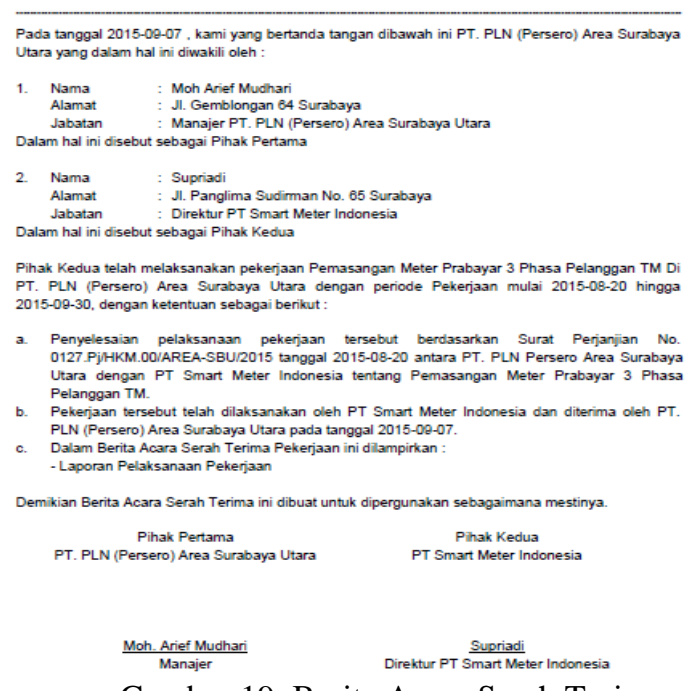

Gambar 19. Berita Acara Serah Terima.

Ketika transaksi melebihi tenggat waktu pekerjaan atau overdeadline, maka akan ada perubahan pada form detil transaksi pekerjaan pada bagian Pengawas Pekerjaan, seperti yang terlihat pada gambar yaitu tambahan sub-form Overdeadline untuk mengisi keterangan tentang catatan keterlambatan pelaksanaan pekerjaan tersebut. 


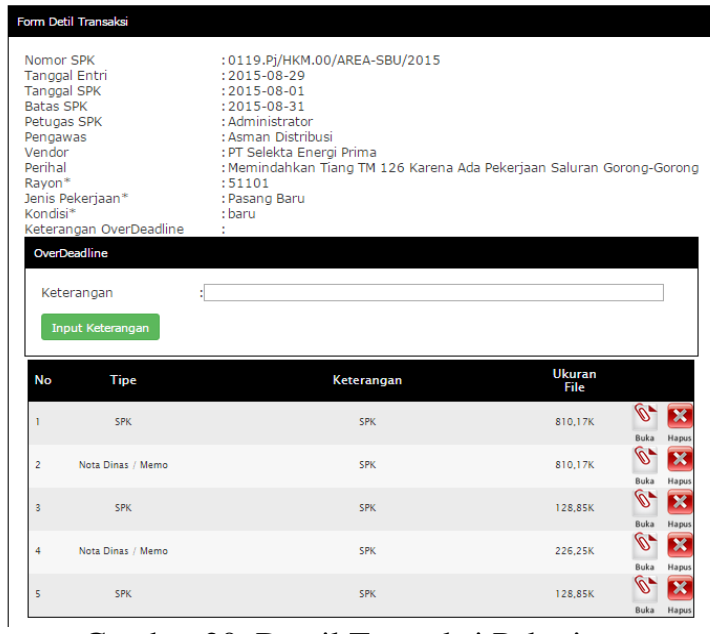

Gambar 20. Detail Transaksi Pekerjaan.

\section{- Form Menu Dahsboard}

Form menu Dashboard hanya dapat diakses oleh user Manajemen dan digunakan untuk melihat grafik berbentuk kolom yang merepresentasikan perkembangan jumlah SPK berdasarkan statusnya, jumlah SPK yang sedang dilaksanakan pengawasannya oleh tiap Pengawas Pekerjaan dan jumlah SPK yang dikategorikan mendekati deadline atau batas akhir pelaksanaan SPK. Data yang direpresentasikan dalam grafik pada menu Dashboard adalah data pada saat bulan berjalan/bulan saat ini. Menu Dashboard dapat dilihat pada gambar berikut.

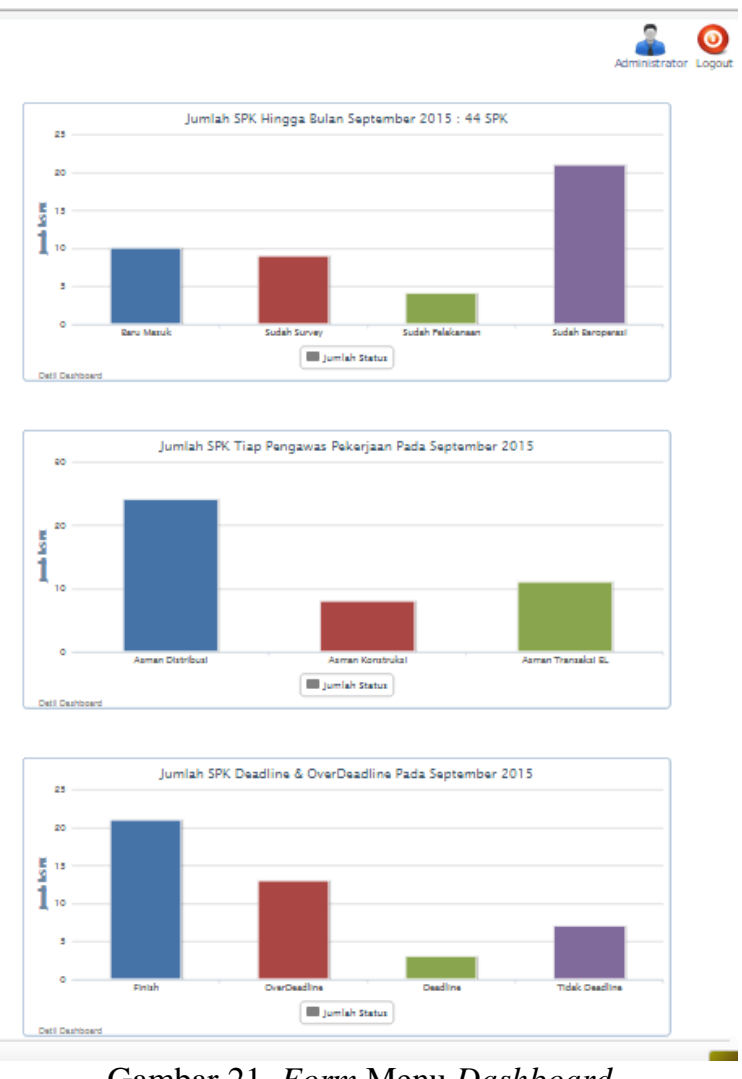

Gambar 21. Form Menu Dashboard.

\section{- Form Menu Laporan}

Form Menu Laporan hanya dapat diakses oleh user Manajemen dan digunakan untuk membuat laporan terkait dengan pelaksanaan pekerjaan yang sudah dimasukan ke dalam sistem. Pada form menu ini, user dapat membuat laporan jumlah pekerjaan berdasarkan dengan waktu tertentu berdasarkan tanggal, bulan dan tahun. Laporan juga dapat dibuat berdasarkan Pengawas Pekerjaan dan Mitra Kerja yang menangani pekerjaan tersebut masing-masing.

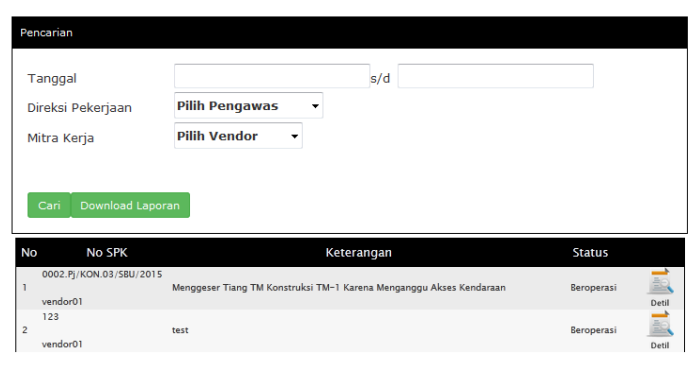

Gambar 22. Form Menu Laporan.

Pada gambar berikutnya diperlihatkan laporan per tanggal yang dapat dihasilkan oleh sistem. Pada tabel yang terdapat dalam laporan, memiliki informasi tentang nomor SPK, Direksi Pekerjaan, Vendor, Tanggal SPK, Tanggal Batas SPK dan Status Pekerjaan.

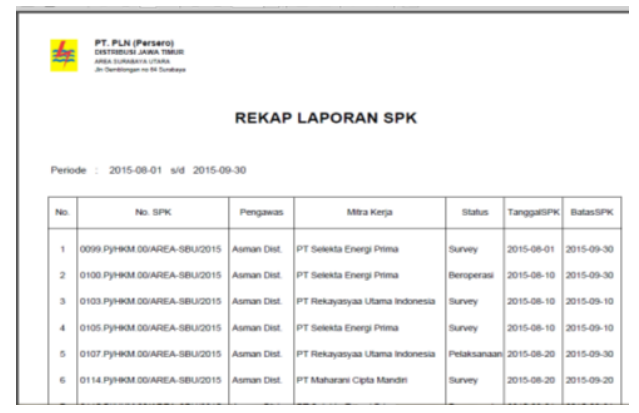

Gambar 23. Rekap Laporan Per Tanggal.

Pada gambar berikutnya diperlihatkan laporan per pengawas pekerjaan yang dapat dihasilkan oleh sistem. Pada tabel yang terdapat dalam laporan, memiliki informasi tentang nomor SPK, Vendor, Perihal Pekerjaan, Tanggal Batas SPK, Status Pekerjaan dan Perihal Pekerjaan.

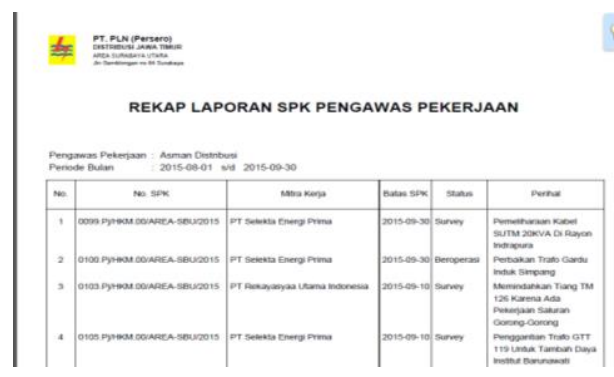

Gambar 24. Rekap Laporan Pengawas. 
Pada gambar berikutnya diperlihatkan laporan per mitra kerja yang dapat dihasilkan oleh sistem. Pada tabel yang terdapat dalam laporan, memiliki informasi tentang nomor SPK, Perihal Pekerjaan, Tanggal SPK, Tanggal Batas SPK dan Status Pekerjaan.

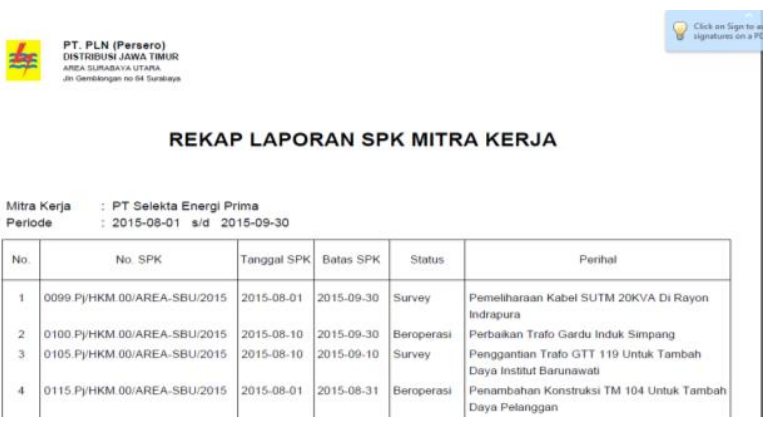

Gambar 25. Rekap Laporan SPK Mitra Kerja.

Pada gambar berikutnya diperlihatkan laporan SPK Deadline yang dapat dihasilkan oleh sistem. Pada tabel yang terdapat dalam laporan, memiliki informasi tentang nomor SPK, Direksi Pekerjaan, Tanggal SPK, Tanggal Batas SPK, Jumlah Hari, Status Transaksi, Status Deadline dan Perihal Pekerjaan.

\section{tat.}

REKAP LAPORAN SPK DEADLINE \& OVERDEADLINE

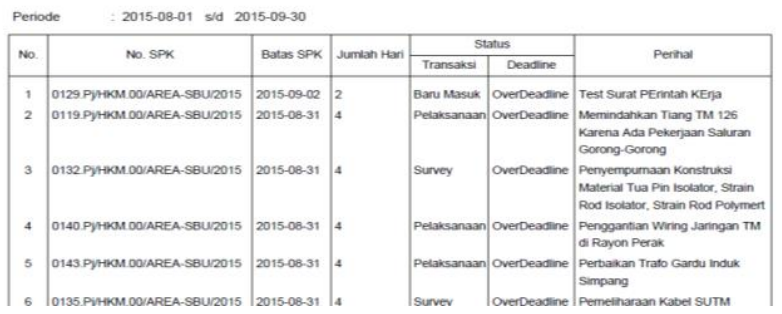

Gambar 26. Rekap Laporan SPK Deadline.

\section{F. Pengujian}

Metode yang digunakan dalam pengujian sistem ini adalah metode White-Box Testing menggunakan Basis Path. Pengujian white-box didasarkan pada pengamatan yang teliti terhadap detil prosedural. Jalur-jalur logika yang melewati perangkat lunak diuji dengan memberikan kasus uji yang menguji serangkaian kondisi dan atau loop tertentu. Status program tersebut dapat diuji pada berbagai titik untuk menentukan apakah status yang diharapkan sesuai dengan status yang sebenarnya. Struktur-struktur data yang penting dapat diperiksa validitasnya.

- Pengujian Pada Menu Input Data SPK

Menu Input Data Surat Perintah Kerja(SPK) adalah salah satu menu utama dalam aplikasi ini. Menu ini hanya dapat diakses oleh user Administrator dan
Petugas SPK. Prosedur yang dilakukan pada menu ini, dijelaskan dengan menggunakan pseudocode berikut.

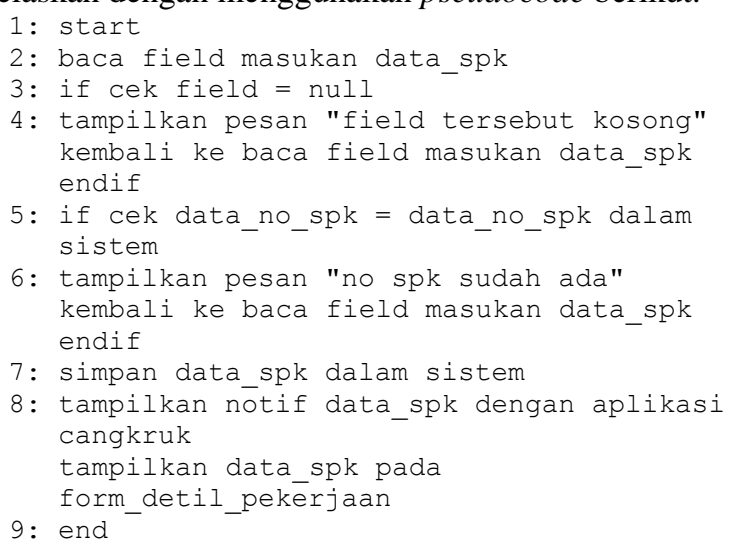

Berikut adalah tabel skenario pengujian menu Input Data SPK.

Tabel 1. Skenario Pengujian Input Data SPK.

\begin{tabular}{|c|c|c|}
\hline Urutan Baris & Skenario & Hasil Diharapkan \\
\hline 1,2 & $\begin{array}{l}\text { Start } \\
\text { baca field masukan data_spk }\end{array}$ & $\begin{array}{l}\text { Mampu membaca } \\
\text { masukan dari user }\end{array}$ \\
\hline 3,4 & $\begin{array}{l}\text { if cek field = null } \\
\text { tampilkan pesan "field } \\
\text { tersebut kosong" } \\
\text { kembali ke baca field } \\
\text { masukan data_spk } \\
\text { endif }\end{array}$ & $\begin{array}{l}\text { Mampu menampilkan } \\
\text { pesan }\end{array}$ \\
\hline 5,6 & $\begin{array}{l}\text { if cek data_no_spk = } \\
\text { data_no_spk dalam sistem } \\
\text { tampilkan pesan "no spk } \\
\text { sudah ada" } \\
\text { kembali ke baca field } \\
\text { masukan data_spk } \\
\text { endif }\end{array}$ & $\begin{array}{l}\text { Mampu menampilkan } \\
\text { pesan }\end{array}$ \\
\hline 7 & simpan data_spk dalam sistem & $\begin{array}{l}\text { Mampu menyimpan ke } \\
\text { dalam database }\end{array}$ \\
\hline 8,9 & $\begin{array}{l}\text { kirim notif data_spk dengan } \\
\text { aplikasi cangkruk } \\
\text { tampilkan data_spk pada } \\
\text { form_detil_pekerjaan } \\
\text { end }\end{array}$ & $\begin{array}{l}\text { Mampu mengirimkan } \\
\text { notifikasi aplikasi } \\
\text { Cangkruk dan form } \\
\text { detil pekerjaan }\end{array}$ \\
\hline
\end{tabular}

Berikut adalah tabel hasil pengujian menu Input Data SPK.

Tabel 2. Hasil Pengujian Input Data SPK.

\begin{tabular}{|l|l|l|}
\hline \multicolumn{1}{|c|}{ Urutan Baris } & \multicolumn{1}{|c|}{ Hasil Pengujian } & Status \\
\hline 1,2 & Mampu membaca masukan dari user & Sesuai \\
\hline 3,4 & Mampu menampilkan pesan & Sesuai \\
\hline 5,6 & Mampu menampilkan pesan & Sesuai \\
\hline 7 & Mampu menyimpan ke dalam database & Sesuai \\
\hline 8,9 & $\begin{array}{l}\text { Mampu mengirimkan notifikasi aplikasi Cangkruk } \\
\text { dan form detil pekerjaan }\end{array}$ & Sesuai \\
\hline
\end{tabular}

Berdasarkan skenario dan hasil pengujian diatas maka dapat digambarkan flowgraph dari menu Input Data SPK seperti pada gambar berikut. 


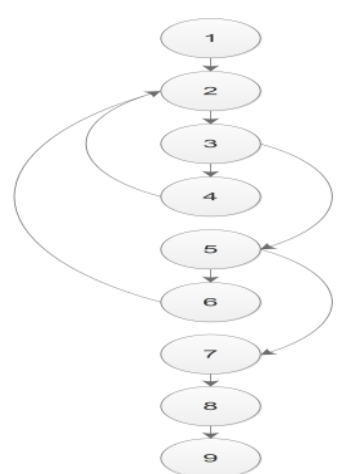

Gambar 27. Flowgraph Menu Input Data SPK.

Untuk perhitungan diatas maka bisa dihitung jumlah path sebagai berikut:

$$
\mathrm{V}(\mathrm{G})=10-9+2=3
$$

Jalur logika (path) yang terjadi pada menu Input Data SPK seperti di bawah ini :

Path $1: 1,2,3,4,2,3,5,6,7-9$

Path 2 : 1,2,3,5,6,2,3,5,7-9

Path $3: 1,2,3,5,7-9$

Graph matrik pada flowgraph menu Input Data SPK diperlihatkan pada tabel berikut:

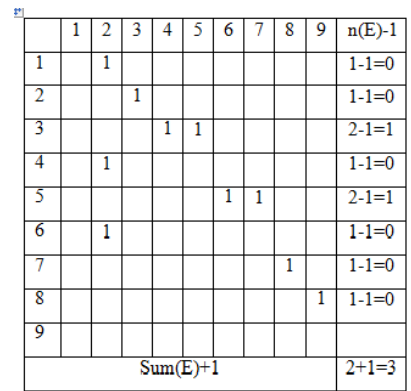

Gambar 28. Graph Matriks Menu Input Data SPK.

- Pengujian pada Form Update Detil Pekerjaan

Form Update Detil Pekerjaan adalah sub-menu untuk menambahkan/meng-upload softcopy dokumen yang berhubungan dengan transaksi yang dilakukan. Menu ini dapat diakses oleh seluruh user yang ada dalam sistem. Prosedur yang dilakukan pada menu ini, dijelaskan dengan menggunakan pseudocode berikut.

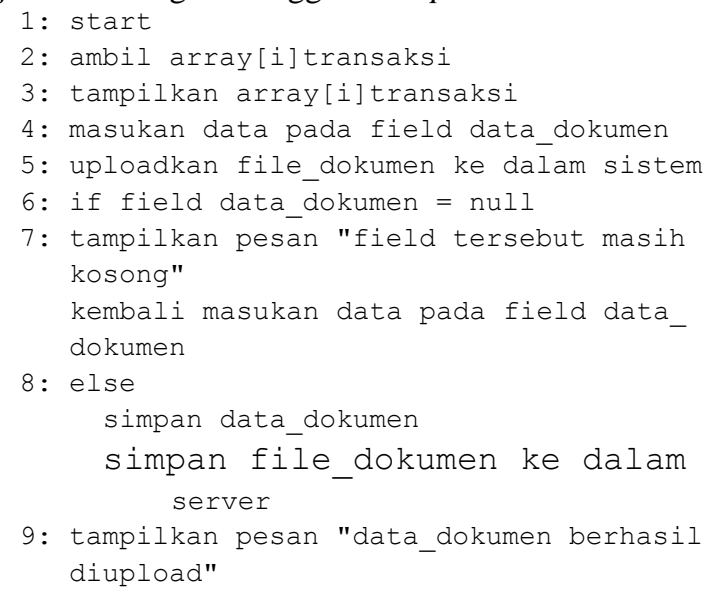

tampilkan tabel data_dokumen endif

10: if button_Selesai $=$ yes

11: tampilkan alert "Apakah tidak upload dokumen lagi?"

12: if button alert $=$ yes

13: tampilkan form_menu transaksi endif endif

14: end

Berikut adalah tabel skenario pengujian Form Update Detil Pekerjaan.

Tabel 3. Skenario Pengujian Form Update Detail

\begin{tabular}{|c|c|c|}
\hline Urutan Baris & Skenario & Hasil Diharapkan \\
\hline 1,2 & $\begin{array}{l}\text { Start } \\
\text { ambil array[i]transaksi }\end{array}$ & $\begin{array}{l}\text { Mampu mengambil data } \\
\text { array transaksi }\end{array}$ \\
\hline 3 & tampilkan array[i] transaksi & $\begin{array}{l}\text { Mampu menampilkan } \\
\text { array transaksi }\end{array}$ \\
\hline 4,5 & $\begin{array}{l}\text { masukan data pada field } \\
\text { data_dokumen } \\
\text { uploadkan file_dokumen ke dalam } \\
\text { sistem }\end{array}$ & $\begin{array}{l}\text { Mampu membaca } \\
\text { masukan data dan file }\end{array}$ \\
\hline 5,7 & $\begin{array}{l}\text { if field data dokumen }=\text { nul1 } \\
\text { tampilkan pesan "field } \\
\text { tersebut masin kosong" } \\
\text { kembali masukan data pada }\end{array}$ & $\begin{array}{l}\text { Mampu menampikan } \\
\text { pesan }\end{array}$ \\
\hline 8,9 & $\begin{array}{l}\text { Else } \\
\text { simpan data_dokumen } \\
\text { simpan file_dokumen ke } \\
\text { dalam server } \\
\text { tampilkan pesan } \\
\text { "data_dokumen berhasil } \\
\text { diupload" } \\
\text { tampilkan tabel } \\
\text { data_dokumen } \\
\text { endif̈ }\end{array}$ & $\begin{array}{l}\text { Mampu menyimpan data } \\
\text { field dan file ke dalam } \\
\text { server serta menampilkan } \\
\text { pesan }\end{array}$ \\
\hline 10,11 & $\begin{array}{l}\text { if button_Selesai = yes } \\
\text { tampilkan alert pesan } \\
\text { "Apakah tidak mengupload } \\
\text { dokumen lagi?" }\end{array}$ & $\begin{array}{l}\text { Mampu menampilkan } \\
\text { pesan }\end{array}$ \\
\hline $12,13,14$ & $\begin{array}{l}\text { if button_alert }=\text { yes } \\
\text { tampilikan } \\
\text { form_menu_transaksi } \\
\text { endif }\end{array}$ & $\begin{array}{l}\text { Mampu menampilkan } \\
\text { pesan }\end{array}$ \\
\hline
\end{tabular}

Berikut adalah tabel hasil pengujian menu Form Update Detail Pekerjaan.

Tabel 4. Hasil Pengujian Menu Form Update Detail Pekerjaan.

\begin{tabular}{|l|l|l|}
\hline Urutan Baris & \multicolumn{1}{|c|}{ Hasil Pengujian } & Status \\
\hline 1,2 & Mampu mengambil data array transaksi & Sesuai \\
\hline 3 & Mampu menampilkan array transaksi & Sesuai \\
\hline 4,5 & Mampu membaca masukan data dan file & Sesuai \\
\hline 6,7 & Mampu menampilkan pesan & Sesuai \\
\hline 8,9 & $\begin{array}{l}\text { Mampu menyimpan data field dan file ke dalam } \\
\text { server serta menampilkan pesan }\end{array}$ & Sesuai \\
\hline 10,11 & Mampu menampilkan pesan & Sesuai \\
\hline $12,13,14$ & Mampu menampilkan pesan & Sesuai \\
\hline
\end{tabular}

Berdasarkan skenario dan hasil pengujian diatas maka dapat digambarkan flowgraph seperti pada gambar. 


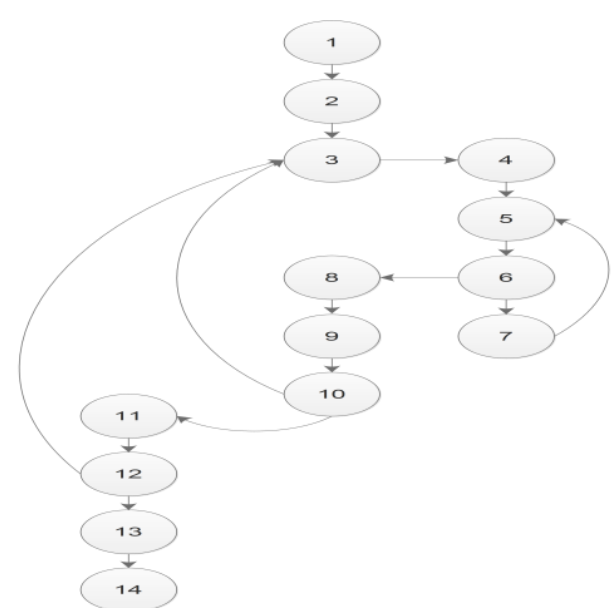

Gambar 29. Flowgraph Menu Form Update Detail Pekerjaan

Untuk perhitungan diatas maka bisa dihitung jumlah path sebagai berikut:

$$
\mathrm{V}(\mathrm{G})=16-14+2=4
$$

Jalur logika (path) yang terjadi pada Form Update Detil Pekerjaan seperti di bawah ini :

Path $1: 1-4,5,6,7,5,6,8-14$

Path 2 : 1-6,8,9,10,3-6,8,9,10,11-14

Path 3 : 1-6,8-11,12,3-6,8-11,12,13,14

Path 4 : 1-6,8-14

Graph matrik pada flowgraph Form Update Detil Pekerjaan diperlihatkan pada tabel berikut

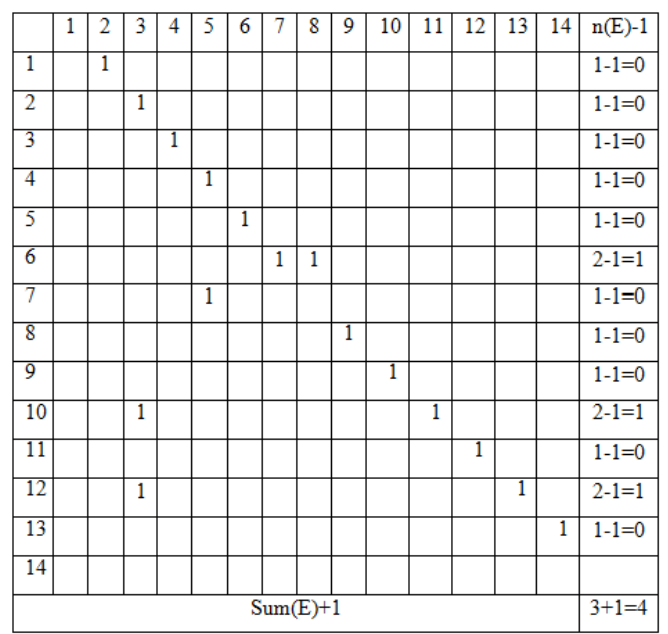

Gambar 30. Graph Matriks Form Update Detil Pekerjaan.

\section{KESIMPULAN DAN SARAN}

A. Kesimpulan

Dari hasil penelitian yang dilakukan mulai dari tahap awal hingga proses pengujian, dapat disimpulkan bahwa dengan diimplementasikannya aplikasi sistem informasi pengawasan pelaksanaan pekerjaan di PT. PLN Area Surabaya Utara, antara lain sebagai berikut :
- Proses pendistribusian informasi pelaksanaan pekerjaan terkait dengan status pelaksanaan pekerjaan dan pengarsipan dokumen menjadi lebih optimal karena seluruh user dalam sistem dapat memantau secara langsung melalui sistem dan aplikasi Cangkruk dengan segera.

- Kinerja pengawas pekerjaan menjadi lebih maksimal dengan adanya menu dashboard yang dapat menjadi acuan bagi pengawas pekerjaan untuk memilah pekerjaan mana yang harus diprioritaskan dan dilaksanakan.

- Penentuan prioritas pekerjaan dalam sistem ini dapat dilihat pada menu transaksi pada tabel transaksi pekerjaan yang memprioritaskan pekerjaan yang melebihi tenggat waktu (overdeadline) dan pekerjaan yang mendekati tenggat waktu (deadline) pada urutan yang utama. Selain itu, terdapat reminder di menu transaksi dan notifikasi otomatis kepada pengawas dan mitra kerja melalui aplikasi Cangkruk untuk pekerjaan yang diprioritaskan.

- Manajemen dapat melihat dan mengunduh rekap laporan pekerjaan pada menu laporan dan grafik pelaksanaan pekerjaan pada menu dashboard sehingga dapat dijadikan acuan untuk perencanaan pekerjaan selanjutnya.

B. Saran

Penulis menyadari bahwa aplikasi ini masih jauh dari kesempurnaan. Oleh karena itu penulis memberikan saransaran yang berguna dalam pengembangan sistem lebih lanjut yaitu:

- Pengembangan aplikasi ini dapat diintegrasikan dengan aplikasi lain di dalam institusi, khususnya untuk Business Process Collaboration.

- $\quad$ Pengembangan notifikasi aplikasi ini yang berbasis XMPP menggunakan aplikasi Cangkruk yang selama ini satu arah dari sistem ke user, agar dapat dikembangkan menjadi dua arah, dimana user dapat menanyakan secara langsung status Surat Perintah Kerja melalui aplikasi Cangkruk tersebut.

\section{REFERENSI}

[1] Gilmore, W. J. (2010). Beginning PHP and MySQL: From Novice to Professional. Apress.

[2] PT. PLN Area Surabaya Utara. (2014). Kontrak Surat Perintah Kerja $($ SPK).

[3] Kadir, A. (2011). Buku Pintar jQuery dan PHP : Untuk Pemula. Yogyakarta: Mediakom.

[4] Kadir, A. (2008). Dasar Perancangan dan Implementasi Database Relasional. Yogyakarta: PANDI.

[5] Teori-Teori Dalam Pengawasan Kerja. http://www.negarahukum.com/hukum/teoripengawasan 